Viçosa, MG, DEA/UFV - DOI: 10.13083/reveng.v29i1.11155

V.29, p.90-99, 2021

\title{
PHYTOEXTRACTION AND NUTRITIONAL QUALITY OF FORAGES CULTIVATED IN A CONSTRUCTED WETLAND SYSTEM FOR WASTEWATER TREATMENT
}

Rubens Ribeiro da Silva ${ }^{1}$ (D), Gilson Araújo de Freitas ${ }^{1}$ (D), Alvaro José Gomes de Faria*2 (D), Jefferson Santana da Silva Carneiro $^{2}$ (D) , Inádia de Jesus Oliveira ${ }^{3}$ (D), Antônio Teixeira de Matos ${ }^{4}$ (D) \& Walter Antônio Pereira Abrahão ${ }^{5}$ (D)

1 - Federal University of Tocantins, Department of Plant Production, Gurupi, TO, Brazil

2 - Federal University of Lavras, Department of Soil Science, Lavras, MG, Brazil

3 - Vale S.A., Imperatriz, Maranhão, Brazil

4 - Federal University of Minas Gerais, Department of Sanitary and Environmental Engineering, Belo Horizonte, MG, Brazil

5 - Federal University of Viçosa, Department of Agronomy, Viçosa, MG, Brazil

\section{Keywords:}

Saline stress

Pennisetum purpureum

Cynodon dactylon

Nutrients

Forage grasses

\section{ABSTRACT}

This study aimed to evaluate the effects of different concentrations of sodium on the phytoextraction of nutrients and nutritional quality of forages (P. purpureum Schum and C. dactylon Pers) grown in wetland system constructed for wastewater generated in cattle slaughterhouses (WGCS) treatment. The experiment was conducted in a randomized complete block design with three replications. The treatments were tested using $2 \times 5$ factorial scheme, as follows: two species of grass (P. purpureum Schum and C. dactylon Pers) and five concentrations of sodium in WGCS: 70, 100, 150, 200 and $250 \mathrm{mg} \mathrm{L}^{-1}$. The phytoextraction potential of nutrients and the nutritional quality of forages grown in pots simulating a wetland system constructed for WGCS with sodium concentrations were assessed in terms of the contents of the nutrients nitrogen, phosphorus, potassium, calcium, magnesium and sodium in leaf tissues. The accumulations of these nutrients in the produced forages were also evaluated. Both species presented different behaviors regarding their nutrient phytoextraction potentials. The nutritional quality was changed in the forages due to the cultivation in constructed wetlands. Forage C. dactylon Pers presented higher phytoextraction potential of sodium and potassium and $P$. purpureum Schum presented a higher nutritional quality.

\section{Palavras-chave: \\ Estresse salino \\ Cynodon dactylon \\ Penissetum purpureum \\ Nutrientes \\ Gramineas forrageiras}

\section{FITOEXTRAÇÃO E QUALIDADE NUTRICIONAL DE FORRAGEIRAS EM SISTEMA ALAGADO CONSTRUÍDO PARA TRATAMENTO DE ÁGUA RESIDUÁRIA \\ RESUMO}

Avaliou-se o efeito de diferentes concentrações de sódio na fitoextração de nutrientes e na qualidade nutricional das forrageiras $P$. purpureum Schum e $C$. dactylon Pers cultivadas em sistema alagado construído para o tratamento de água residuária gerada em frigoríficos bovinos (ARFB). O experimento foi conduzido em delineamento experimental de blocos casualizados com três repetições. Os tratamentos foram testados em esquema fatorial 2 x 5 , sendo: duas forrageiras (P. purpureum Schum e C. dactylon Pers) e cinco concentrações de sódio na ARFB: $70,100,150,200$ e $250 \mathrm{mg} \mathrm{L}^{-1}$. O potencial de fitoextração de nutrientes e a qualidade nutricional das forrageiras cultivadas em vasos simulando um sistema alagado construido para ARFB com as concentrações de sódio foi avaliada por meio dos teores dos nutrientes nitrogênio, fósforo, potássio, cálcio, magnésio e sódio nos tecidos foliares e da acumulação desses nutrientes na forragem produzida. As forrageiras $P$. purpureum Schum e $C$. dactylon Pers apresentaram respostas diferentes quanto ao potencial de fitoextração de nutrientes e a qualidade nutricional foi alterada nas forrageiras em função do cultivo no ambiente alagado construído. A forrageira C. dactylon Pers apresenta maior potencial em fitoextração de sódio e potássio e a forrageira $P$. purpureum Schum apresenta maior qualidade nutricional.
90

SECTION EDITOR IN CHARGE André Pereira Rosa
Recebido para publicação em 18/09/2020 • Aprovado em 13/05/2021 • Publicado em 21/06/2021 Email (corresponding author)*: ajgomesdefaria@hotmail.com 


\section{INTRODUCTION}

Although wastewater generated in cattle slaughterhouses (WGCS) is considered a byproduct rich in nutrients, its use for the fertigation of agricultural crops can be limited due to its high salinity and the presence of heavy metals, which requires adequate treatment (SHELEF et al., 2012; THEBALDI et al., 2013). The accumulation of salts in the root zone causes the development of osmotic stress and ion influx by the cell membrane, affecting ionic homeostasis and cellular absorption of nutrients such as potassium $\left(\mathrm{K}^{+}\right)$, calcium $\left(\mathrm{Ca}^{2+}\right)$ and nitrogen $\left(\mathrm{NO}_{3}^{-}\right)$In addition, it causes the absorption and accumulation of toxic ions such as sodium $\left(\mathrm{Na}^{+}\right)$and chlorine $\left(\mathrm{Cl}^{-}\right)$. There are also changes in hormonal balance and gene expression, as well as reduction in water absorption and changes in inorganic and organic solute concentrations (GUIMARÃES, 2005; AQUINO et al., 2007; WILLADINO; CAMARA, 2010).

WGCS can be improved by implementing wetland systems (MATOS et al., 2012). These systems, in addition to providing wastewater treatment, allow the recycling of nutrients through the production of plants that act as sinkholes for various elements, improving water quality and leaving nutrients and metals toxic levels at acceptable levels (MATOS et al., 2010; SHELEF et al., 2012; BHATIA; GOYAL, 2013; CAI et al., 2013; HERATH; VITHANAGE, 2015). However, the success of the implementation of this treatment system in the cattle slaughterhouses depends on the choice and tolerance of the plant species to the condition of cultivation in aqueous environment and the presence of high and variable concentrations of $\mathrm{Na}^{+}$(MATOS et al., 2010; MATOS et al., 2012; AVELAR et al., 2015).

Constructed wetland systems are artificial ecosystems that use plants grown on substrates such as soil, sand and gravel, where physical, chemical and biochemical processes of treatment of wastewater occur. The mechanisms involved in the treatment are: filtration, microbial degradation of organic matter and phytoextraction of nutrients, among others (MATOS et al., 2010, 2012; CHAVAN; DHULAP, 2012; SHELEF et al., 2012; WU et al., 2014; AVELAR et al., 2015). Plants use nutrients from wastewater for their growth, acting as extractors of most macro and micronutrients of the wastewater under treatment, which accumulate in their biomass (MATOS et al., 2010; CHAVAN; DHULAP, 2012; BHATIA; GOYAL, 2013; HERATH; VITHANAGE, 2015).

Constructed wetland systems have been proposed and used in the treatment of wastewater (e.g., dairy products, coffee agroindustry, and pig farming) after undergoing the process of stabilization in a pond systems (FIA et al., 2008; MATOS et al., 2008, 2010, 2012). Several plant species that are naturally adapted to wetlands have been grown, including grass species, such as the forages $C$. dactylon Pers e P. purpureum Schum. These species are adapted to tropical conditions and have been successfully used in the treatment of agro-industrial wastewater (MATOS et al., 2008, 2009, 2010, 2012).

However, research results are not yet found in the literature reporting the effect of sodium $\left(\mathrm{Na}^{+}\right)$ concentrations on the nutrient phytoextraction potential and the nutritional quality of $C$. dactylon Pers e $P$. purpureum Schum when grown in a wetland system constructed for WGCS treatment. We hypothesized that forages grown in a wetland system constructed for WGCS, would be able to remove sodium from the residual water and accumulate in the aerial part without affecting its nutritional quality. Therefore, this study aimed to evaluate the effect of different $\mathrm{Na}$ concentrations on the phytoextraction of nutrients and nutritional quality of $P$. purpureum Schum e C. dactylon Pers grasses when grown in a wetland system constructed for WGCS treatment.

\section{MATERIAL AND METHODS}

This study was carried out in partnership between Federal University of Viçosa (UFV), Federal University of Tocantins (UFT) and the Cooperative of Meat and Derivatives Producers of Gurupi (COOPERFRIGU). The implementation of the experiment with the cultivation of the forages in the constructed wetland systems was conducted in the municipality of Gurupi, state of Tocantins, Brazil (geographical coordinates $11^{\circ} 43^{\prime} 45^{\prime \prime} \mathrm{S}$ and $49^{\circ} 04^{\prime} 07^{\prime \prime} \mathrm{W}$, altitude of $280 \mathrm{~m}$ ). The climate of the 
region is humid with moderate water deficiency. The average annual temperature is $29.5{ }^{\circ} \mathrm{C}$ and the average annual precipitation is $1.804 \mathrm{~mm}$ (ALVARES et al., 2013).

The experiment was installed in a randomized block design with three replications. A total of ten treatments were obtained in a factorial arrangement of $2 \times 5$, in which the first factor consists of two forage species (P. purpureum Schum e C. dactylon Pers) and the second factor by five concentrations of sodium in WGCS, being 70, 100, 150, 200 e 250 $\mathrm{mg} \mathrm{L}^{-1}$. Each concentration was prepared using a cattle wastewater with an initial concentration of 70 mg Na L ${ }^{-1}$, the other concentrations were obtained with the addition of $\mathrm{NaCl}$ for analysis $(39.3 \%$ of $\mathrm{Na}$ ), until reaching the desired concentration.

The physical, chemical and biochemical characterization of the cattle wastewater collected in the Australian system composed of four ponds at COOPERFRIGU are: Temperature: $30.1{ }^{\circ} \mathrm{C}$; Turbidity: 68.9 NTU (nephelometric turbidity unit); Electric conductivity: $2057 \mu \mathrm{S} \mathrm{cm} \mathrm{cm}^{-1} ; \mathrm{pH}$ : 7.99; Dissolved oxygen: $0.0 \mathrm{mg} \mathrm{L}^{-1} \mathrm{O}_{2}$; Chemical oxygen demand (COD): $401.0 \mathrm{mg} \mathrm{O}_{2} \mathrm{~L}^{-1}$; Biochemical oxygen demand (BOD): $233.0 \mathrm{mg} \mathrm{O}_{2}$ $\mathrm{L}^{-1}$; COD/BOD: 1.72; Oils and greases: $18.2 \mathrm{mg}$ $\mathrm{L}^{-1}$; sedimentable solids: $0.1 \mathrm{mg} \mathrm{L}^{-1}$; suspended solids: $102.0 \mathrm{mg} \mathrm{L}^{-1}$; N: $184.51 \mathrm{mg} \mathrm{L}^{-1}$; Cr: 0.05 mg L-1; P: $11.16 \mathrm{mg} \mathrm{L}^{-1}$; Na: $70.0 \mathrm{mg} \mathrm{L}^{-1} ; \mathrm{K}: 26.4$ mg L${ }^{-1}$; $\mathrm{Zn}: 0.40 \mathrm{mg} \mathrm{L}^{-1}$; Ca: $43.38 \mathrm{mg} \mathrm{L}^{-1}$; $\mathrm{Mg}$ : $16.32 \mathrm{mg} \mathrm{L}^{-1}$; Ni: $0.03 \mathrm{mg} \mathrm{L}^{-1}$; Mn: $5.14 \mathrm{mg} \mathrm{L}^{-1}$; Mo: $0.02 \mathrm{mg} \mathrm{L}^{-1}$; Co: $0.02 \mathrm{mg} \mathrm{L}^{-1}$; $\mathrm{Cu}: 0.06 \mathrm{mg}$ $\mathrm{L}^{-1}$; and $\mathrm{Cd}: 0.01 \mathrm{mg} \mathrm{L}^{-1}$. The wastewater used in this study was collected in the fourth pond of the Australian system, after the initial treatments.

Forage P. purpureum Schum was obtained at the University Campus of Gurupi, while the seedlings of $C$. dactylon Pers were donated by the Farm Brilhant, also located in the municipality of Gurupi - TO. The seedlings were submitted to standardization in an average size of 25 and $30 \mathrm{~cm}$, and mean nodes of three and two to P. purpureum Schum and $C$. dactylon Pers, respectively. The wetland system were constructed with pot polyethylene, with a capacity of $12 \mathrm{dm}^{3}, 30 \mathrm{~cm}$ in diameter, $25 \mathrm{~cm}$ in height and useful area of cultivation of $0.049 \mathrm{~m}^{2}$. A vegetative propagule was planted per pot. Thirty days after planting, a uniformity cut was performed at the height of five centimeters for $C$. dactylon Pers and fifteen centimeters for $P$. purpureum Schum.

The macronutrient contents, yield and dry matter of shoot were used for the evaluation of the phytoextraction potential in the two forage species (P. purpureum Schum e C. dactylon Pers). Thus, the plants were subjected to monthly cuts at 30,60 and 90 days after cutting uniformity, as suggested by Rodrigues et al. (2006). Based on the obtained results, extrapolation of the production area to one hectare of wetland system constructed was carried out $\left(10.000 \mathrm{~m}^{2}\right)$ in the 12 -month period. The green mass of each forage species was weighed and placed in a greenhouse with forced air circulation at $60{ }^{\circ} \mathrm{C}$ for 72 hours. After drying, the samples were weighed again to obtain the shoot dry matter, followed by grinding.

To evaluation of the nutrient phytoextraction potential and the nutritional quality of the forages, analyses were carried out to determine the contents of $\mathrm{N}, \mathrm{P}, \mathrm{K}, \mathrm{Na}, \mathrm{Ca}$, and $\mathrm{Mg}$ in the shoot of each forage species. The fitoextration capacity was based only in the forages uptake. Thus, the contents of elements such as $\mathrm{N}, \mathrm{P}, \mathrm{K}, \mathrm{Ca}, \mathrm{Mg}$ and $\mathrm{Na}$ in the wastewater were not measured after the experiment. The $\mathrm{N}$ content was determined by the Kjeldahl method with digestion with concentrated sulfuric acid. The other elements were obtained through digestion with nitric and perchloric acids (MALAVOLTA et al., 1997). Atomic absorption spectrophotometry was used for the contents of $\mathrm{Ca}$ and $\mathrm{Mg}$, flame emission spectrometry for $\mathrm{K}$ and $\mathrm{Na}$ and colorimetry for total $\mathrm{P}$.

The obtained results were submitted to variance and regression analyses using the SISVAR software (FERREIRA, 2011). Regression models were chosen based on the significance of the regression equation coefficients and determination coefficient, using the t-test at 1 and $5 \%$ probability levels.

\section{RESULTS AND DISCUSSION}

The sodium concentration used in the study significantly affected the phytoextraction capacity of the studied forages. Both forage species $P$. purpureum Schum and $C$. dactylon Pers presented different responses regarding their 
nutrient phytoextraction potential with different concentration of Na in WGCS (Figure 1), probably due to their different tolerances to sodium and nutrient use efficiency in this condition. Regarding $\mathrm{N}$, it was verified a quadratic response for both forages. P. purpureum Schum showed an increase in $\mathrm{N}$ phytoextraction up to the concentration of $136.45 \mathrm{mg} \mathrm{Na} \mathrm{L}^{-1}$ (Figure 1A). At higher $\mathrm{Na}$ concentrations, the phytoextraction potential was reduced, becoming equal to that obtained by forage C. dactylon Pers at the Na concentration of $250 \mathrm{mg}$ $\mathrm{L}^{-1}$ in WGCS. As for $C$. dactylon Pers, despite a reduction in the potential for $\mathrm{N}$ phytoextraction due to increased concentration of Na in WGCS, there was an increase in the phytoextraction of $\mathrm{N}$ at concentrations of $\mathrm{Na}$ higher than 200

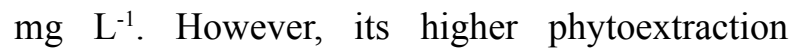
potential (463 $\mathrm{kg} \mathrm{ha}^{-1}$ year $\left.{ }^{-1}\right)$ was achieved only at $\mathrm{Na}$ concentration of $250 \mathrm{mg} \mathrm{L}^{-1}$, but this value corresponds to just over $50 \%$ of the phytoextraction potential observed for P. purpureum Schum. On the other hand, the potential for $\mathrm{N}$ phytoextraction observed for $C$. dactylon Pers at Na concentration of $250 \mathrm{mg} \mathrm{L}^{-1}$ was similar to the phytoextraction of $544 \mathrm{~kg} \mathrm{ha}^{-1}$ year $^{-1}$ in dairy wastewater observed by Matos et al. (2008) and higher than that obtained by Matos et al. (2010). However, it is less than the phytoextraction of $963 \mathrm{~kg} \mathrm{~N} \mathrm{ha}^{-1}$ year $^{-1}$ in swine wastewater, observed by Matos et al. (2009).

According to Vilela (2005), despite having average phytoextraction of $77 \mathrm{~kg} \mathrm{~N}^{-1}$ year $^{-1}, P$. purpureum Schum presents a genetic potential for phytoextraction higher than $800 \mathrm{~kg} \mathrm{ha}^{-1}$ year $^{-1}$. In the present study, the greatest genetic potential of $P$. purpureum Schum for $\mathrm{N}$ phytoextraction in WGCS occurred when cultivation was carried out with the concentration of $136.45 \mathrm{mg} \mathrm{Na} \mathrm{L}^{-1}$ that provided a phytoextraction of $\mathrm{N}$ in the order of 863 $\mathrm{kg} \mathrm{ha}^{-1}$ year ${ }^{-1}$ in this $\mathrm{Na}$ concentration, reaching its genetic potential described by Vilela (2005).

Regarding the nutrients $\mathrm{P}, \mathrm{Ca}$ and $\mathrm{Mg}$, a higher potential for phytoextraction was also observed for P. purpureum Schum when compared with C. dactylon Pers (Figure 1B, E, F). However, at $\mathrm{Na}$ concentration of $250 \mathrm{mg} \mathrm{L}^{-1}$ the potential for phytoextraction of $\mathrm{P}, \mathrm{Ca}$ and $\mathrm{Mg}$ was the the same for both the forage species. These findings show that high $\mathrm{Na}$ concentrations negatively affect the phytoextraction capacity of these nutrients by the studied forages.

In relation to $\mathrm{P}$, both forages used in this study obtained a reduction in the $\mathrm{P}$ phytoextraction potential with the increase in $\mathrm{Na}$ concentrations, especially for P. purpureum Schum. For C. dactylon Pers, the greatest effects on reducing the potential for phytoextraction as a function of salinity occurred only when the concentration of $\mathrm{Na}$ in WGCS was higher than $200 \mathrm{mg} \mathrm{L}^{-1}$ (Figure 1B). The phytoextraction potential of $\mathrm{P}$ by $C$. dactylon Pers (approximately $80 \mathrm{~kg} \mathrm{ha}^{-1} \mathrm{year}^{-1}$ ) when grown in a wetland system constructed for WGCS treatment was higher than $61 \mathrm{~kg} \mathrm{ha}^{-1}$ year ${ }^{-1}$ found in dairy wastewater by Matos et al. (2008) and $38.7 \mathrm{~kg} \mathrm{ha}^{-1}$ year ${ }^{-1}$ found by Matos et al. (2010). However, it is less than the extraction observed by Matos et al. (2009) in swine wastewater, which was $127 \mathrm{~kg} \mathrm{ha}^{-1}$ year ${ }^{-1}$. This shows that the genetic potential for the $\mathrm{P}$ phytoextraction by $C$. dactylon may be greater than the results presented in this work under $\mathrm{Na}$ concentrations in WGCS. In addition, the P level of the wastewater used is higher than the level of the present study, and the $\mathrm{Na}$ levels are lower.

For C. dactylon Pers, the phytoextraction of $\mathrm{Ca}$ and $\mathrm{Mg}$ remained constant in the initial $\mathrm{Na}$ concentrations and showed an increase in the potential for phytoextraction for $\mathrm{Ca}$ and $\mathrm{Mg}$ in a concentration of $\mathrm{Na}$ higher than 226.7 and 195.92 $\mathrm{mg} \mathrm{L}^{-1}$, respectively. In contrast, despite the greater phytoextraction of $\mathrm{Ca}$ and $\mathrm{Mg}$ by $P$. purpureum Schum, it is observed that the phytoextraction potential of this forage drastically reduced as the $\mathrm{Na}$ concentrations increased, reaching values similar to that obtained for $C$. dactylon Pers at the $\mathrm{Na}$ maximum concentration $\left(250 \mathrm{mg} \mathrm{L}^{-1}\right)$. Thus, in the implementation of a wetland system constructed for WGCS treatment with Na high concentrations (> $100 \mathrm{mg} \mathrm{Na} \mathrm{L}^{-1}$ ), it is suggested the cultivation of C. dactylon Pers.

Differently from $\mathrm{N}, \mathrm{P}, \mathrm{Ca}$ and $\mathrm{Mg}$, in which the highest phytoextraction was verified in the cultivation of forage $P$. purpureum Schum, $\mathrm{K}$ and $\mathrm{Na}$ were extracted in higher contents by $C$. dactylon Pers (Figure 1). Forage C. dactylon showed increasing $\mathrm{Na}$ phytoextraction potential with increasing of $\mathrm{Na}$ concentrations in WGCS. The phytoextraction potential of $C$. dactylon Pers for 

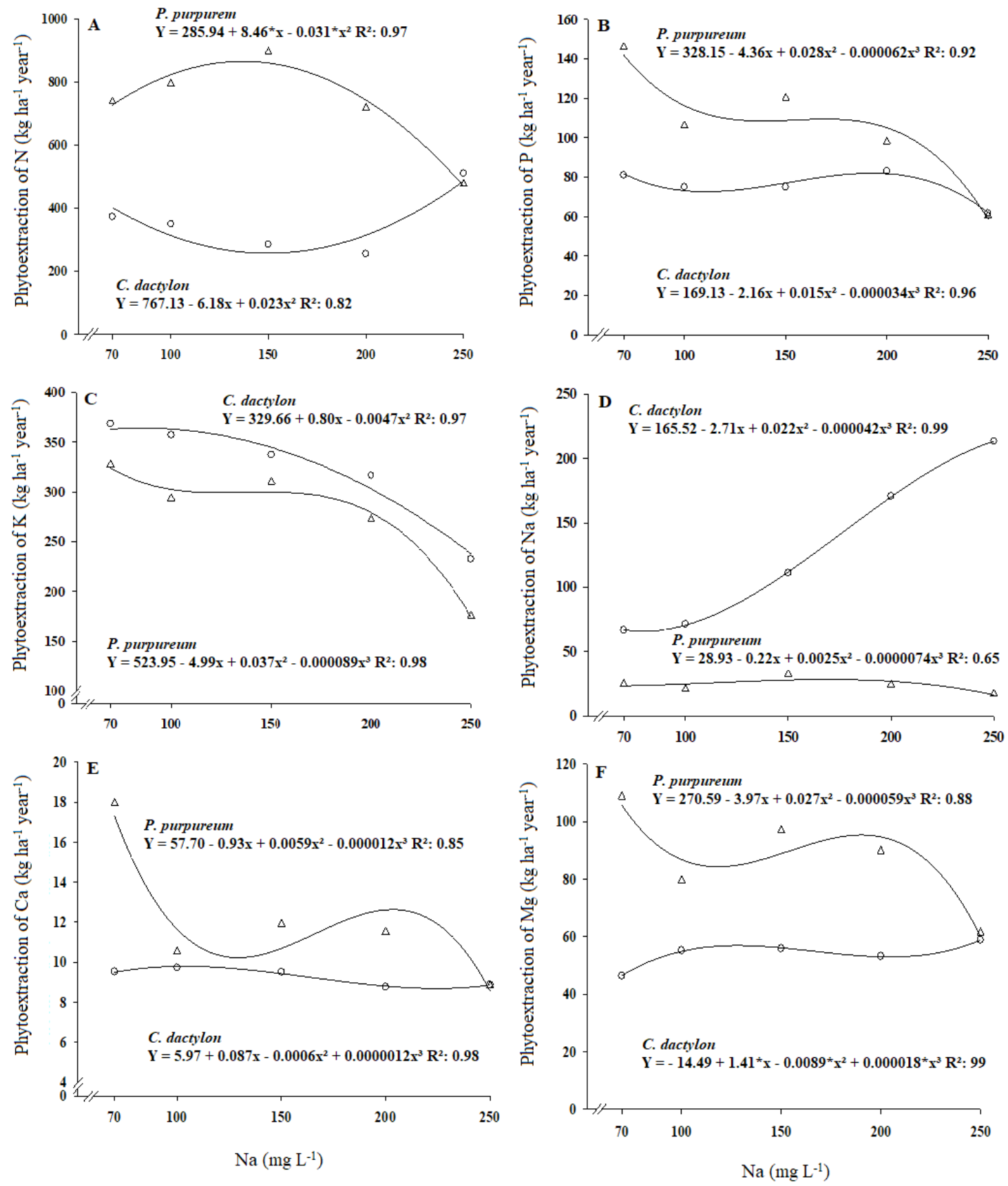

Figure 1. Yearly phytoextraction potential for $\mathrm{N}, \mathrm{P}, \mathrm{K}, \mathrm{Ca}, \mathrm{Mg}$ and $\mathrm{Na}$ by Cynodon dactylon Pers and Pennisetum purpureum Schum when grown in a wetland system constructed for wastewater generated in cattle slaughterhouses treatment with different concentrations of $\mathrm{Na}$. $\mathrm{Y}: \hat{\mathrm{Y}}=$ corresponds to the estimated value of the indicator

$\mathrm{Na}$ in the concentration of $250 \mathrm{mg} \mathrm{L}^{-1}$ was 14 times higher than that observed for P. purpureum Schum. This indicates a greater potential of $C$. dactylon Pers to be used in wetland system constructed for WGCS treatment with high concentrations of Na.

Regarding $\mathrm{K}$, both forages showed a reduction in the phytoextraction potential due to the increase in Na concentrations in WGCS (Figure 1C). The maximum phytoextraction potential of $\mathrm{K}$ by $P$. purpureum Schum was only $50 \%$ of its genetic potential $\left(594 \mathrm{~kg} \mathrm{~K} \mathrm{ha}^{-1}\right.$ year $\left.^{-1}\right)$ considering a soil cultivation with an optimal supply of this nutrient (VILELA, 2005). Matos et al. (2009), when evaluating the potential for nutrient extraction 
by forage $C$. dactylon Pers in a wetland system used for swine wastewater treatment, observed an extraction of $591 \mathrm{~kg} \mathrm{~K} \mathrm{ha}^{-1}$, which is higher than that observed in the present study, even in the lower concentrations of $\mathrm{Na}$ in WGCS. However, the extraction potentials of 204 and $129 \mathrm{~kg} \mathrm{~K} \mathrm{ha}^{-1}$ verified by Matos et al. (2008) and Matos et al. (2010), respectively, in dairy wastewater were lower than that extracted in WGCS when the concentration of $\mathrm{Na}$ was lower than $200 \mathrm{mg} \mathrm{L}^{-1}$ in the present study. This lower $\mathrm{K}$ phytoextraction occur because in low concentrations of $\mathrm{Na}$, some grasses can benefit from this element in a beneficial way, which can replace $\mathrm{K}$ in some functions without causing damage to plants. Thus, the plant increases the absorption and accumulation of $\mathrm{Na}$ in relation to K (CARNEIRO et al., 2017; SILVA et al., 2020).

The nutrient compositions in $P$. purpureum Schum and $C$. dactylon Pers were altered due to cultivation in WGCS with increasing concentrations of $\mathrm{Na}$ (Figure 2). However, except for the contents of $\mathrm{K}$ in P. purpureum Schum, which presented values below $11 \mathrm{~g} \mathrm{~kg}^{-1}$, and $\mathrm{Ca}$ which presented values lower levels than $3 \mathrm{~g} \mathrm{~kg}^{-1}$ in both forages, the other nutrients presented higher contents than those observed by Malavolta et al. (1997) and Vilela (2005), considered as suitable for both forages when grown in soil.

The contents of $\mathrm{N}$ were higher in P. purpureum Schum when compared with $C$. dactylon Pers, with levels higher than $12 \mathrm{~g} \mathrm{~kg}^{-1}$, which was also higher than that observed by Malavolta et al. (1997) and Vilela (2005). This $\mathrm{N}$ content represents a minimum necessary guarantee for rumen micro-organisms in adult cattle (SILVA et al., 2008). In both forages, a cubic response was verified in the accumulated $\mathrm{N}$ content according to the different concentrations of $\mathrm{Na}$ in WGCS (Figure 2A). The content of $\mathrm{N}$ increased in $C$. dactylon Pers and P. purpureum Schum when they were grown in WGCS with a concentration of up to 114.92 and $124.88 \mathrm{mg} \mathrm{Na}$ $\mathrm{L}^{-1}$, respectively. At higher concentrations of $\mathrm{Na}$, the contents of $\mathrm{N}$ show a decreasing behavior with the increase in the concentration of $\mathrm{Na}$, until reaching the values of 180.5 and $223.38 \mathrm{mg} \mathrm{Na}$ $\mathrm{L}^{-1}$, respectively. When a relationship is made with the phytoextraction of this element, it is observed that $P$. purpureum extracts less $\mathrm{N}$ in a higher concentration of $\mathrm{Na}$ than $C$. dactylon, however its composition of $\mathrm{N}$ is higher (Figure 1A).

The highest levels of $\mathrm{N}$ found in P. purpureum Schum indicates a change in the nutritional balance imposed by the presence of the saline effect. Usually, higher contents of $\mathrm{N}$ are found in $C$. dactylon Pers. Guimarães (2005) pointed out that there are higher $\mathrm{N}$ absorption at high concentrations of $\mathrm{Na}$. The increase in the contents of $\mathrm{N}$ at high concentrations of Na in WGCS makes it possible to produce forage with high nutritional quality even in periods of absence of rain.

Regarding $\mathrm{P}, \mathrm{Ca}$ and $\mathrm{Mg}$, higher contents were verified in P. purpureum Schum than in C. dactylon Pers. For both forages, a cubic effect on the content of accumulated $\mathrm{P}$ according to the concentration of Na in WGCS was observed. The contents of $\mathrm{P}$ were reduced when forage plants were grown in WGCS containing increasing concentrations of $\mathrm{Na}$ (Figure 2B). After a concentration of $200 \mathrm{mg} \mathrm{Na}$ $\mathrm{L}^{-1}$ the contents of $\mathrm{P}$ showed the highest reductions in the levels of leaf $\mathrm{P}$ for both forages. This result is probably due to the low phytoextraction capacity and accumulation of $\mathrm{P}$ in the $\mathrm{Na}$ highest concentration $\left(>200 \mathrm{mg} \mathrm{Na} \mathrm{L}^{-1}\right)$ in both forages tested in this study, as observed in Figure 1B.

Both forages, regardless of the concentration of $\mathrm{Na}$ in WGCS, presented $\mathrm{P}$ contents that would meet the requirements of $\mathrm{P}$ in dry matter (2.8 to $3.7 \mathrm{~g} \mathrm{~kg}^{-1}$ ) for a dairy cow with $400 \mathrm{~kg}$ of live weight and productivity ranging from 7 the 20 $\mathrm{kg}$ milk per day (NRC, 1989). The contents of $\mathrm{P}$ were superior to $1.8 \mathrm{~g} \mathrm{~kg}^{-1}$ in fodder of $C$. dactylon Pers fertigated with wastewater generated in the breeding of dairy cattle (ERTHAL et al., 2010). Moreover, they represented increases of three to four times in the content considered appropriate $\left(0.8 \mathrm{~g} \mathrm{~kg}^{-1}\right)$ (MALAVOLTA et al., 1997; VILELA, 2005). Contents of $P$ higher than $20 \mathrm{~g} \mathrm{~kg}^{-1}$ in forage makes the supplement of this nutrient for beef cattle expendable.

As for $\mathrm{Ca}$ and $\mathrm{Mg}$, a cubic effect was also verified on the accumulated contents in $C$. dactylon Pers depending on the concentration of Na in WGCS. The content of $\mathrm{Ca}$ increased when the forages was grown in WGCS containing up to $109.48 \mathrm{mg} \mathrm{Na}$ $\mathrm{L}^{-1}$ (Figure 2E). After this $\mathrm{Na}$ concentration, the 

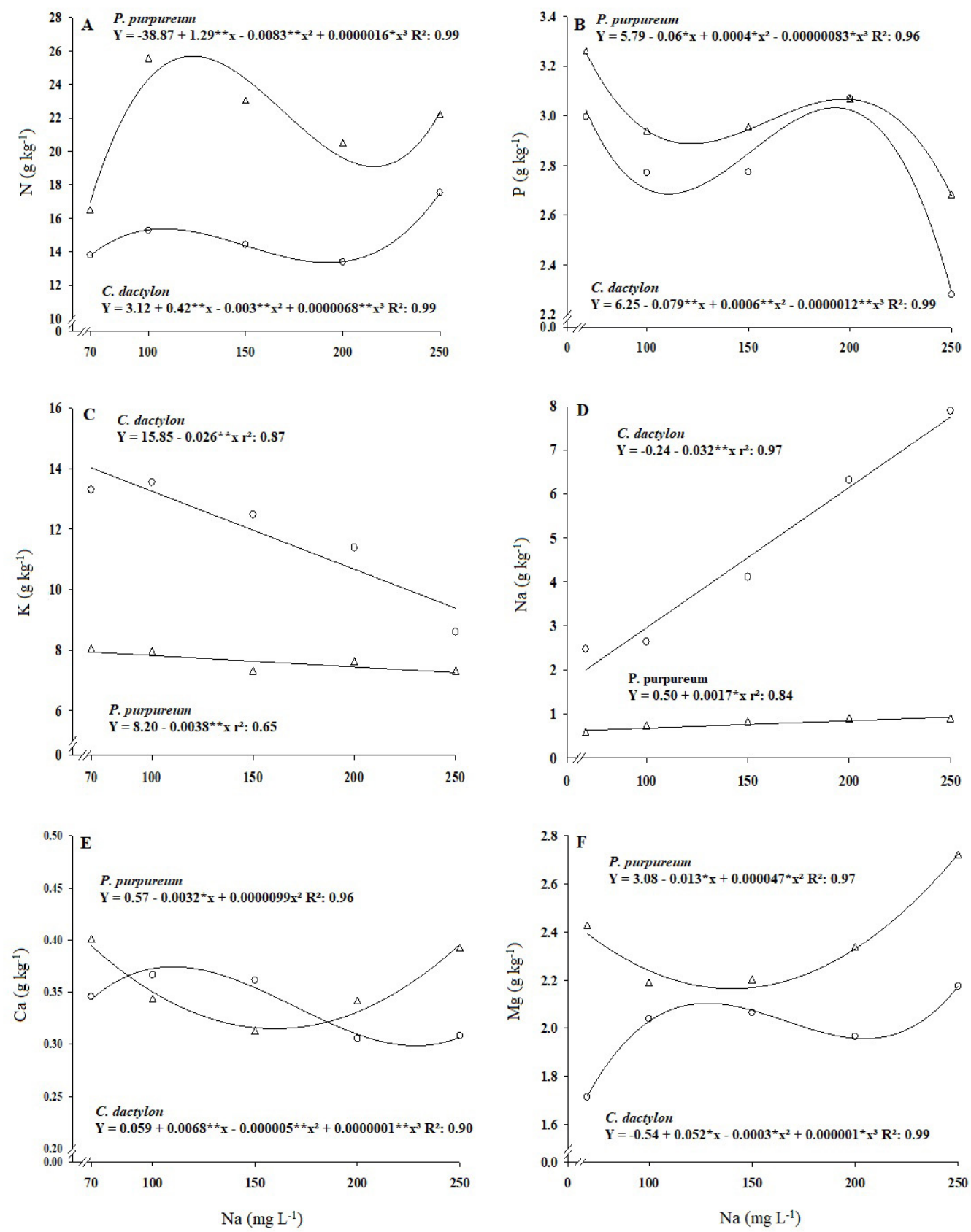

Figure 2. Average of macronutrients levels in Cynodon dactylon Pers and Pennisetum purpureum Schum when grown in a wetland system constructed for wastewater generated in cattle slaughterhouses treatment with different concentrations of $\mathrm{Na}$ for three cycles of 30 days. $\mathrm{Y}: \hat{\mathrm{Y}}=$ corresponds to the estimated value of the indicator

contents of $\mathrm{Ca}$ have decreased with the increase in the concentration of $\mathrm{Na}$, until $227.52 \mathrm{mg} \mathrm{Na} \mathrm{L}^{-1}$. At higher concentrations, there are more accumulation of leaf $\mathrm{Ca}$. As for $\mathrm{Mg}$, a similar response was found. However, the effect of the increase in the concentration of $\mathrm{Na}$ accumulation of this nutrient was lower (Figure 2F).

In $P$. purpureum Schum, a quadratic response was found for the accumulated $\mathrm{Ca}$ and $\mathrm{Mg}$ contents depending on the concentration of $\mathrm{Na}$ in WGCS. The contents of $\mathrm{Ca}$ decreased when the forages was cultivated with doses up to $161.62 \mathrm{mg} \mathrm{Na}$ $\mathrm{L}^{-1}$. After this concentration of $\mathrm{Na}$, the content of $\mathrm{Ca}$ presented an increasing behavior due to the increase in the concentration of $\mathrm{Na}$ until $250 \mathrm{mg}$ $\mathrm{L}^{-1}$. In relation to the nutrient $\mathrm{Mg}$, the leaf content 
presented a decreasing behavior only until the concentration of $139.78 \mathrm{mg} \mathrm{Na} \mathrm{L}^{-1}$.

It is important to highlight that the results of the elemental composition for $\mathrm{Ca}$ and $\mathrm{Mg}$ in C. dactylon Pers followed a standard behavior similar to that observed in the phytoextraction of this element, regardless of the $\mathrm{Na}$ concentration applied (Figure 1E and 1F). On the other hand, it is observed that forage P. purpureum extracted less $\mathrm{Ca}$ and $\mathrm{Mg}$ mainly when subjected to a higher $\mathrm{Na}$ concentration $\left(250 \mathrm{mg} \mathrm{L}^{-1}\right)$. Nevertheless, its elemental composition of $\mathrm{Ca}$ and $\mathrm{Mg}$ remained at increasing levels under these conditions (Figure 2E and $2 \mathrm{~F}$ ).

As for the nutritional quality, both forages presented levels higher than $1.0 \mathrm{~g} \mathrm{Mg} \mathrm{kg}^{-1}$, which is a value considered suitable for beef grazing (MALAVOLTA et al., 1997; VILELA, 2005), as well as for beef cattle (NRC, 1989). The contents obtained were also higher than $1.3 \mathrm{~g} \mathrm{Mg} \mathrm{kg}^{-1}$, observed for Erthal et al. (2010) in C. dactylon Pers grass fertigated with wastewater generated in the breeding of dairy cattle. In this study, both forages present levels of $\mathrm{Mg}$ that characterize a nutritional enrichment nearly twice the levels that are considered appropriate.

Contrary to the nutritional enrichment based on the leaf content of $\mathrm{Mg}$, the contents of Ca verified in both forages are considered very low (Figure 2E). The observed contents, regardless of the cultivated forage, were approximately 10 times lower than the contents considered ideal by Vilela (2005) and Silva et al. (2008), which might be explained by the presence of high sodium concentration, which might have inhibited the absorption of $\mathrm{K}, \mathrm{Ca}$ and Mg.

The leaf contents of $\mathrm{K}$ reduced with the increase in the concentration of $\mathrm{Na}$ (Figure 2C) in both forages. C. dactylon Pers showed a greater reduction in the contents of $\mathrm{K}$ when compared with P. purpureum Schum. This result was directly proportional to the findings for the phytoextraction of this element, in which $\mathrm{K}$ phytoextraction also decreased with increasing $\mathrm{N}$ concentrations (Figure 1C), mainly for P. purpureum Schum. The $\mathrm{K}$ contents in the leaves might have been inhibited by the high $\mathrm{Na}$ concentrations, through the antagonism that exists between these two ions
(Figure 2D). In fact, other authors have observed the existence of multiple absorption systems with different selectivities for $\mathrm{Na}$ and $\mathrm{K}$, which may reflect the plant's need to coordinate the influx of these cations (GUIMARÃES, 2005).

However, even though there were great reductions in the contents of $\mathrm{K}$ in $C$. dactylon Pers, the observed values are still considered adequate. According to Malavolta et al. (1997) and Vilela (2005), $\mathrm{K}$ contents superior to $11 \mathrm{~g} \mathrm{~kg}^{-1}$ are considered appropriate for the rearing of beef cattle. Unlike C. dactylon Pers, P. purpureum Schum showed variations in the contents of $K$ close to 8 $\mathrm{g} \mathrm{kg}^{-1}$, which can be considered a value of medium nutritional quality, according to the same authors. Erthal et al. (2010), when evaluating the effect of the application of different residue water slides generated in the breeding of dairy cattle on the cultivation of $C$. dactylon Pers, verified an average leaf contents of $1.78 \mathrm{~g} \mathrm{~K} \mathrm{~kg}^{-1}$ in the first cut. In the assessment of the nutritional quality to meet the requirements of $\mathrm{K}$ in dairy cattle feeding $\left(9.0 \mathrm{~g} \mathrm{~kg}^{-}\right.$ ${ }^{1}$ ), the contents $\mathrm{K}$ were higher (NRC, 1989) only in C. dactylon Pers.

As for $\mathrm{Na}, P$. purpureum Schum and $C$. dactylon Pers presented a linear response to the accumulation of this element according to the increasing concentrations of Na in WGCS (Figure 2D). However, C. dactylon Pers presented a higher accumulation of $\mathrm{Na}$ on the leaves than P. purpureum Schum. This result is directly linked to the greater phytoextraction capacity of $\mathrm{Na}$ that $P$. purpureum Schum has in relation to $C$. dactylon Pers when subjected to $\mathrm{Na}$ in increasing concentrations in a wetland system constructed for treatment of WGCS (Figure 1F), corroborating with the results of the $\mathrm{Na}$ content in the aerial part obtained for both forage species.

The highest accumulation in $C$. dactylon Pers might be related to increased accumulations in vacuoles as well as greater efficiency in replacing $\mathrm{K}$ for $\mathrm{Na}$. Excess $\mathrm{Na}$ results in damage mainly to older leaves, providing initial burns along the edges, which might even evolve throughout the leaf, causing necrosis. However, for $C$. dactylon Pers no symptoms of toxicity were verified, even though a cumulative content of $\mathrm{Na}$ higher than $6 \mathrm{~g}$ $\mathrm{kg}^{-1}$ was observed. 


\section{CONCLUSIONS}

- Forage C. dactylon Pers presented greater phytoextraction potentials of $\mathrm{Na}$ and $\mathrm{K}$, while $P$. purpureum Schum presented greater phytoextraction potentials of $\mathrm{N}, \mathrm{P}, \mathrm{Ca}$ and $\mathrm{Mg}$.

- Forage P. purpureum Schum presented higher nutritional quality when compared with $C$. dactylon Pers, except for calcium, which was higher only in the first and last sodium concentration used in this study.

- The cultivation of both forages, P. purpureum Schum and $C$. dactylon Pers, in wetland system constructed for the wastewater generated in cattle slaughterhouses treatment promotes an increase in the nutritional quality of the plants, except for $\mathrm{K}$ and $\mathrm{Ca}$, in which there are reductions in the leaf levels due to increasing sodium concentrations.

\section{AUTHORSHIP CONTRIBUTION STATEMENT}

SILVA, R.R.: Data curation, Formal Analysis, Investigation, Methodology, Writing - original; FREITAS, G.A.: Data curation, Investigation, Methodology, Writing - original draft; FARIA, A.J.G.: Formal Analysis, Investigation, Validation, Writing - original draft; CARNEIRO, J.S.S.: Formal Analysis, Investigation, Validation, Writing - original draft; OLIVEIRA, I.J.: Data curation, Investigation, Validation, Visualization; MATOS, A.T.: Conceptualization, Methodology, Supervision, Validation, Visualization; ABRAHÃO, A.P.: Conceptualization, Project administration, Supervision, Validation, Writing review \& editing

\section{DECLARATION OF INTERESTS}

The authors declare that they have no known competing financial interests or personal relationships that could have appeared to influence the work reported in this paper.

\section{ACKNOWLEDGEMENTS}

The authors thank the COOPERFRIGU, Higher Education Personnel Improvement Coordination (CAPES) and National Council for Scientific and Technological Development (CNPq).

\section{REFERENCES}

ALVARES, C.A.; STAPE, J.L.; SENTELHAS, P.C.; GONÇALVES, J.L.M.; SPAROVEK, G. Köppen's climate classification map for Brazil. Meteorologische Zeitschrift, v.22, p.711-728, 2013.

AQUINO, A.J.S.; LACERDA, C.F.; BEZERRA, M.A.; GOMES FILHO, E.; COSTA, R.N.T. Growth, dry matter partition, and retention of $\mathrm{Na}^{+}$, $\mathrm{K}^{+}$, and $\mathrm{Cl}^{-}$in two genotypes of sorgo irrigated with saline waters. Brazilian Journal of Soil Science, v.31, p.961-971, 2007.

AVELAR, F.F.; MATOS, A.T.; JÚNIOR, A.R.L.; PORTES, M.R.; GUALHANO, D.S. Performance agronomic of mentha aquatic cultivated in flooded systems built under different organic application rates. Agricultural Engineering, v.35, n.2, p. 322330, 2015.

BHATIA, M.;GOYAL, D. Analyzing remediation potential of wastewater through wetland plants: a review. Environmental Progress \& Sustainable Energy, v.33, p.9-27, 2013.

CAI, T.; PARK, S.Y.; LI, Y. Nutrient recovery from wastewater streams by microalgae: status and prospects. Renewable and Sustainable Energy Reviews, v.19, p.360-369, 2013.

CARNEIRO, J.S.S.; SILVA, P.S.S.; SANTOS, A.C.M.; FREITAS, G.A.; SANTOS, A. C.; SILVA, R. R.. Mombaça grass responds to partial replacement of $\mathrm{K}^{+}$by $\mathrm{Na}^{+}$with supplemental $\mathrm{Ca}^{2+}$ addition in low fertility soil. Journal of Agricultural Science, v. 9, n. 11, p. 209-219, 2017.

CHAVAN, B.L.; DHULAP, V.P. Sewage treatment with Constructed Wetland using Panicum maximum forage Grass. Journal of Environmental Science and Water Resources, v.1, p.223-230, 2012.

ERTHAL, V.J.; FERREIRA, P.A.; PEREIRA, O.G.; MATOS, A.T. Physiological, nutritional characteristics and yield of forage fertigated with cattle-growing wastewater. Brazilian Journal of Agricola and Environmental EngineeringAgriambi, v.14, p.458-466, 2010. 
FERREIRA, D.F. SISVAR: A computer statistical analysis system. Ciência e Agrotecnologia, v. 35, n. 6, p. 1039- 1042, 2011.

GUIMARÃES, F.V. Physiological and biochemical responses in rope bean plants cv Pitiúba subjected to stress with $\mathrm{NaCl}$ concentrations of $\mathrm{CaCl}$ and CaSO. Doctoral Thesis (Doctorate in Plant Biochemistry)-Federal University of Ceará, Fortaleza, 2005.

HERATH, I.; VITHANAGE, M. Phytoremediation in constructed wetlands. In: Ansari, A.A., S.S. Gill, R. Gill, G.R. Lanza and L. Newman. Phytoremediation: Management of Environmental Contaminants ( $2 \mathrm{a}$ ed), Springer International Publishing, Switzerland, 2015.

MALAVOLTA, E.; VITTI, G.C.; OLIVEIRA, S. A. Evaluation of the nutritional status of plants: principles and applications/Euripipedes Malavolta, Godofredo Cesar Vitti, Sebastião Alberto de Oliveira.-2. ed., ver. e atual. Piracicaba: Potafos, 1997.

MATOS, A.T.; ABRAHÃO, S.S.; LO MONACO, P. A. V. Efficiency of flooded systems built in the removal of wastewater pollutants from the dairy industry. Agricultural Engineering, v.32, p.11441155, 2012.

MATOS, A.T.; ABRAHÃO, S.S.; MONACO, P.A.; SARMENTO, A.P.; MATOS, M. P. Plant extractor capacity in flooded systems used in the treatment of dairy wastewater. Brazilian Journal of Agricola and Environmental Engineering, v.14, n.12, p. 1311-1317, 2010.

MATOS, A.T.; ABRAHÃO, S.S.; PEREIRA, O.G. Performance agronomic grass tifton 85 (Cynodon spp) cultivated in built-in flooded systems used to treat dairy wastewater. Ambiente \& Água-An Interdisciplinary Journal of Applied Science, v.3, n.1, p.43-53, 2008.

MATOS, A.T.; FREITAS, W.D.S.; LO MONACO, P.A.V. Extracting capacity of different plant species grown in flooded systems used in the treatment of wastewater of pig farming. Ambiente \& Água-An Interdisciplinary Journal of Applied Science, v.4, n.2, p.31-45, 2009.
National Research Council (US). Nutrient requirements of dairy cattle (N. 3), 1958.

RODRIGUES, L.R.A.; RODRIGUES, T.D.J.; REIS, R.A.; SOARES FILHO, C.V. Evaluation of physiological characteristics of five cultivars of Cynodon. Acta Scientiarum. Animal Sciences, v.28, n.3, p.245-250, 2006.

SHELEF, O.; GROSS, A.; RACHMILEVITCH, S. The use of Bassia indica for salt phytoremediation in constructed wetlands. Water research, v.46, p.3967-3976, 2012.

SILVA, P.S.S., LEITE, R.C.; CARNEIRO, J.S.S.; FREITAS, G.A.; R. R. SILVA, R.R. Mombaça grass development with partial replacement of potassium fertilizer by sodium chloride and the effects of adding calcium. Tropical GrasslandsForrajes Tropicales, v.8 n. 3, p. 195-202, 2020.

SILVA, S.C.; NASCIMENTO JÚNIOR, D.; EUCLIDES, V.B.P. Pastures: basic concepts, production, and management. Viçosa: Suprema, 2008.

THEBALDI, M.S.; SANDRI, D.; FELISBERTO, A.B.; ROCHA, M.S.; NETO, S. A. Water quality for irrigation of a stream after receiving treated effluent from bovine slaughter. Agricultural Engineering, v.33, n.3, p.109-120, 2013.

VILELA, H. Pasture: selection of forage plants, implantation, and fertilization. Viçosa: Aprenda Fácil, 2005.

WILLADINO, L.; CAMARA, T.R. Plant tolerance to salinity: physiological and biochemical aspects. Biosphere encyclopedia, v.6, n.11, p.123, 2010.

WU, S.; KUSCHK, P.; BRIX, H.; VYMAZAL, J.; DONG, R. Development of constructed wetlands in performance intensifications for wastewater treatment: a nitrogen and organic matter targeted review. Water research, v.57 p.40-55, 2014. 